\title{
Creating local institutional arrangements for sustainable wetland socio-ecological systems: Lessons from the 'Striking a Balance' project in Malawi
}

\author{
Alan Dixon and Rachael Carrie \\ Institute of Science and the Environment, University of Worcester, Henwick Grove, Worcester, WR2 6AJ, UK
}

\begin{abstract}
Wetland socio-ecological systems provide livelihood benefits for many poor people throughout the developing world, yet their sustainable development requires local utilisation strategies that balance both environmental and development outcomes. Community-based local institutional arrangements that mediate peoples' relationships with their environment and facilitate adaptive co-management offer one means of achieving this, and increasingly many NGOs and development practitioners have sought to integrate local institutional capacity-building into development projects. In the context of wider academic debates surrounding the long-term sustainability of externally-facilitated local institutions, this paper draws on the experiences of the three-year Striking a Balance (SAB) project in Malawi which sought to embed sustainable wetland management practices within community-based local institutional arrangements. Drawing on field data collected through participatory methods at three project sites some five years after the cessation of project activities, we examine the extent to which SAB's local institutional capacitybuilding has been successful, and from this draw some lessons for externally-driven project interventions which seek win-win outcomes for people and the environment. With reference to Elinor Ostrom's design principles for long-enduring common property resource institutions, we suggest that the observed declining effectiveness of SAB's local institutions can be attributed to issues of stakeholder inclusiveness and representations; their sustainability was arguably compromised from their inception on account of them being nested within pre-existing, externallydriven village 'clubs' whose membership and decision-making was not congruent with all the wetland stakeholders within the community.
\end{abstract}

\section{Keywords}

Local institutions, socio-ecological systems, dambos, wetland management, sustainable development, Malawi

\section{Introduction}

During the last 20 years there has been a gradual shift in attitudes towards Africa's wetlands, characterised in the discourse by a move away from an emphasis on wetlands as resources to be conserved for biodiversity, to an arguably more humanistic approach that recognises the complex interactions that people have with wetland systems, not least in terms of the ways in which they contribute to livelihoods and poverty reduction around the continent. The Millennium Development Goals, which have had far reaching implications in terms of donor priorities in development and conservation policy-making, were a key stage in this process of redefining the international wetlands agenda, and in 2006, the Millennium Ecosystem Assessment took this further by emphasising the contribution of wetland ecosystem services to peoples' well-being (MA 2005). This shift in focus has subsequently lead some to assert that wetland conservation per se is no longer a viable or indeed ethical option throughout Africa, given the continued development needs of the majority of the population (Wood et al. 2013). Through their provision of ecosystem services, wetlands, it seems, have become critical resources in the fight against poverty (Ramsar 2005; Schuyt 2005; Kumar et al. 2011; Finlayson et al. 2011; Adekola et al. 2015). Moreover, wetland agriculture, traditionally considered a significant cause of wetland loss and degradation, is increasingly being re-examined in the context of the need to balance environmental and development needs (Dixon \& Wood 2005; CA 2007; Wood \& van Halsema 2008; Rebelo et al. 2010; McCartney et al. 2010; Wood et al. 2013). 
This focus on the relationship between wetlands and livelihoods has reignited classic debates concerning sustainable development, particularly in terms of the ways in which natural resources or ecosystem services can be managed in a manner which is environmentally, socially and economically sustainable (WCED, 1987; Roe \& Elliott 2004; Emerton 2005; Holden \& Linnerud 2007; Fisher et al. 2005). Although the Ramsar Bureau has been committed for many years to supporting and advocating the principle of 'wise use', which stresses the need for sustainable development (Ramsar 1987, 2005), it has until fairly recently shied away from any real discussion of the need for people in developing countries to utilise wetlands beyond the extraction of forage and craft materials, medicinal plants, and fish, principally because of the perceived risks of more intensive agricultural use leading to environmental degradation. Yet, as highlighted by Wood et al. (2013) contemporary debates on sustainable development have shifted the agenda firmly beyond simplistic neo-Malthusian interpretations of people-environment relationships and inevitable ecological collapse, to more systemic approaches that emphasise the dynamic and adaptive interrelationships between ecological and social systems. Socio-ecological systems theory in particular (Berkes \& Folke 1998; Berkes et al. 2003; Ostrom 2009), presents a framework for analysing environment-society interactions which, it argues, draws upon widespread empirical evidence of the importance of human agency; people continuously adapt, organize and negotiate their relationship with resources and the environment and have a vested interested in sustaining the social, economic and environmental benefits from this relationship. Those socio-ecological systems considered sustainable, are inherently resilient and demonstrate adaptive capacity, i.e. they are able to buffer and absorb shocks and pressures whilst continuing to function, whereas less resilient systems are more sensitive to external pressures, vulnerable to environmental degradation and ultimately unsustainable (Adger 2000; Folke et al. 2002; Berkes et al. 2003).

Redefining wetlands as socio-ecological systems, therefore, clearly has advantages in terms of focusing policy-makers and planners' attention on two key entry points at the core of sustainability: enhancing resilience and adaptive capacity (Anderies et al. 2004). Whereas in ecological systems these are enshrined in biodiversity in terms of colonisation and adaptation to changes in the physical environment, in social systems adaptive capacity and resilience are manifest in community-based institutional arrangements for natural resource management, as well as other forms of social and human capital (Ostrom 1990; Berkes, 1999; Adger 2000; Berkes et al. 2003; Olsson et al. 2004). Local institutional arrangements include shared formal or informal rules and understandings that can relate to issues such as resource boundaries, land access and distribution, collective action, reciprocal work arrangements and conflict resolution (Rasmussen \& Meinzen-Dick 1995). Being endogenous in nature they have been regarded as 'home grown' adaptations to NRM problems (Shivakumar 2003), and hence have greater credibility, relevance and legitimacy for local communities, compared to top-down externally-driven institutions. In terms of sustainability, empirical evidence suggests that they can represent socially sustainable structures that support environmentally and economically sustainable resource management outcomes (Ostrom 1990; Blunt \& Warren 1996; Uphoff 1992; Howes 1997; Hinchcliffe et al. 1999; Koku \& Gustafsson 2001; Pretty \& Ward 2001; Mazzucato \& Niemeijer 2002). It is perhaps unsurprising, therefore, that NGOs and government agencies have increasingly sought to 'tap into' this relationship and place the empowerment of local institutions on the development agenda (Pretty \& Ward 2001; Ribot et al. 2008).

Of primary concern here is whether this can ever be feasible and successful in practice, especially since the notion of externally-driven (NGO) community-based (local) institutional arrangements appears inherently contradictory at best. However, while some have suggested that any external intervention in the operations of local institutions constitutes a threat to their legitimacy, credibility and effectiveness (Richards 1997; Watson 2003), an examination of the literature relating to common property resource (CPR) institutions reveals a complex situation in which a range of variables, or so-called 'enabling conditions' (Agrawal 2001, p. 1659) are highlighted as critical in defining external-local institutional relationships and their potential for sustainable socio-ecological systems. Elinor Ostrom's 'design principles illustrated by long-enduring CPR institutions' (Ostrom 1990, p. 90), continue to represent a relevant framework for assessing the effectiveness of local institutional arrangements and their relationship with external actors (Agrawal 2001; Anderies et al. 2004; Quinn et al. 2007; Cox et al. 2010) not least because 
there is an emphasis on local knowledge, devolved decision-making and individual rights to organise, alongside a pragmatic recognition that these systems are inevitably shaped by an external policy environment and do not exist within an institutional vacuum. Ostrom's assertion that '...the rights of appropriators to devise their own institutions are not challenged by external governmental authorities' (Ostrom 1990, p. 90) is key. Clearly, the implication here is that it is not the intervention per se, but rather the nature of it, that is the critical variable. Indeed, as Mansbridge (2014) emphasises, Ostrom regarded external actors such as government as playing a productive role in supporting complex CPR institutional arrangements as long as the rights and decision-making power of the nested local institution is respected.

Playing a productive role in supporting institutional arrangements is a key challenge for even the most enlightened NGOs working at the environment-development nexus, or indeed any external actor, and it is this challenge that this paper seeks to address through reviewing the experiences of a specific project intervention. The Striking a Balance (SAB) project implemented between 2005 and 2008 in central Malawi, was an externally-driven initiative that drew on the experitise of several development NGOs to achieve the aim of reducing poverty and sustaining a range of ecosystem services among wetland-dependent communities. As we discuss in the following sections, central to SAB's implementation was a component of local institutional development which specifically aimed to embed mechanisms for socio-ecological sustainability within community-based institutional arrangements. Drawing on field evidence emerging from a post-project evaluation study, the local institutional legacy of the SAB project is analysed and discussed with particular references to Ostrom's design principles.

\section{Wetlands and livelihoods in Malawi}

Wetlands exist in various forms throughout central Southern Africa, ranging from permanent and extensive swamps to seasonally flooded stream and river valleys, and grassland plains with seasonally high water tables known locally as dambos (Balek \& Perry 1973; Thomas \& Goudie 1985; Boast 1990; von der Heyden 2004). Estimates suggest that these wetlands account for between $2 \%$ and $4 \%$ of the total land area of Malawi, and some $12 \%$ of the total cultivable land area (Mloza-Banda 2005) and have long supported a range of important ecosystem services including the provision of water, fishing, grazing, seasonal agriculture and wild plant collection (Roberts 1988; Noble 1996; Wood \& Thawe 2013).

In the last two decades, periodic droughts in Malawi have led to increased winter / dry season dambo cultivation by many households in order to supplement reduced upland harvests (Chisinga \& Kayuni 2011; Wood \& Thawe 2013). Dambo cultivation uses either residual moisture in the soil, hand irrigation or medium-cost technologies such as treadle pumps to draw water from shallow wells (Kambewa 2005). While this clearly represents a climate change-driven adaptive survival strategy to many, in a growing number of cases the expansion of dambo cultivation is an adaptive diversification strategy by farmers who seek to take advantage of new market opportunities. Consequently, as is the case with wetlands throughout Africa, dambos have become a new agricultural frontier (Dixon \& Wood 2003, Msusa 2011; Wood et al. 2013).

Intensification in the use of dambos across Malawi arguably represents a new challenge for local communities in terms of their capacity to manage the use of these natural resources in a manner which sustains the economic, environmental and social benefits they provide. Experience elsewhere in Southern Africa has shown that dambo exploitation can lead to soil erosion, gully formation, water shortages and subsequently the loss of dambo-based livelihood opportunities (Faulkner \& Lambert 1990; McFarlane \& Whitlow 1990). There are also conflicts over use of these resources as people compete for access and control (Chisinga \& Kayuni, 2011). There is, therefore, a key need to identify the ways in which local people use and manage dambos, identify potential threats to their sustainability, but critically, to identify ways in which their ecosystem services can be sustained in the face of increasing pressure to transform these areas. As social structures that can regulate and mediate the use of natural resources, community-based institutions arguably have a critical role to play in the development of sustainable dambo management strategies. 


\section{The Striking a Balance (SAB) Project}

Between 2005 and 2008 the 30-month project, 'Striking a Balance: Maintaining Seasonal Wetlands and their Livelihood Contributions in Central Southern Africa', explored how seasonal wetlands in Zambia and Malawi could be managed in a way that balanced and sustained ecosystem service provision alongside livelihood benefits. Specifically, the project aimed to support sustainable wetland management through what was termed a 'Functional Landscape Approach' (FLA) (Wood \& Thawe 2013), which included the development of local institutional arrangements as a means of embedding sustainable use at the local level. The project was initiated under the management of Wetland Action EEIG in partnership with NGOs Harvest Help and Find Your Feet, and funded by the Dutch government through Wetlands International. In Malawi the local partner NGO, Malawi Enterprise Zone Association (MALEZA), was responsible for field implementation of the project activities within the Simlemba Traditional Authority area in Kasungu District (Figure 1). There, the SAB project added to the overall on-going wetland activities of MALEZA's Simlemba Sustainable Rural Livelihoods Project (SSRLP), which began in 2005 (Msusa 2011). The SAB project was implemented at three sites in Simlemba District in Malawi (Figure 1): Malawila $\left(12^{\circ} 40^{\prime} 31.14^{\prime \prime S}\right.$ $\left.33^{\circ} 35^{\prime} 29.34^{\prime \prime E}\right)$, Katema (12 $\left.43^{\prime} 22.08^{\prime \prime S} 33^{\circ} 35^{\prime} 56.40^{\prime \prime E}\right)$ and Chiotha (12 $\left.46^{\circ} 41.82^{\prime \prime S} 33^{\circ} 40^{\prime} 23.40^{\prime \prime E}\right)$.

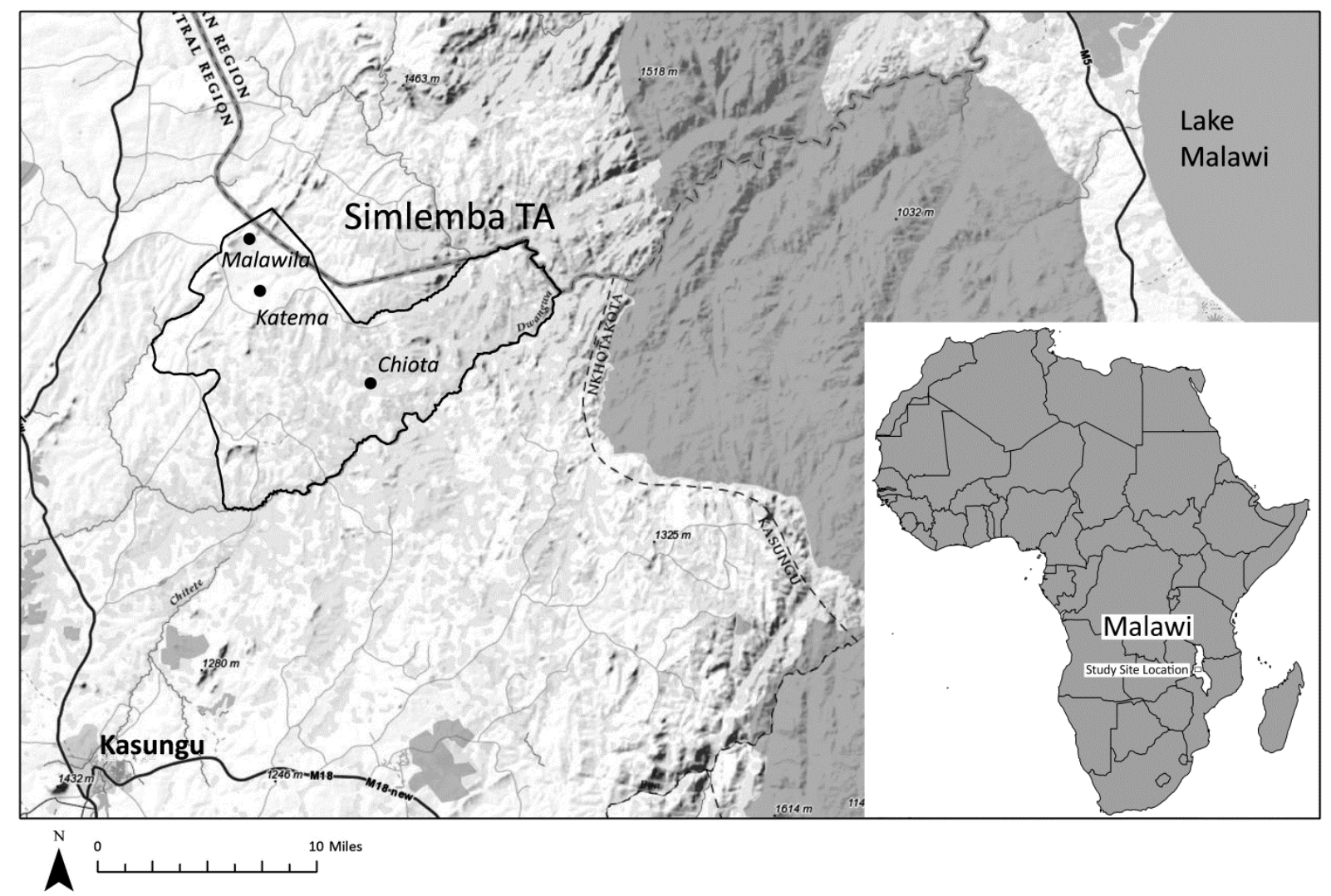

Figure 1 - Location of the three SAB sites within Simlemba TA.

\section{a) $S A B$ and the Functional Landscape Approach}

The $S A B$ approach essentially draws upon a holistic, socio-ecological systems view of the dynamic relationship between people and the environment, in both space and time. It applies this to the specific context of wetlands and their catchments, and has led to the development of the FLA concept which recognises how different landscape units are linked, and how specific interventions and management strategies can support and sustain these inter-related ecosystem services and livelihoods (Wood \& Thawe 2013). It draws upon a range of ideas from various disciplines including integrated catchment management (Newson 1997; Lenton \& Muller 2009), socio-ecological systems (Berkes \& Folke 1998) ecological networks and mosaics (Mimet et al. 2013) ecoagriculture (Scherr \& McNeely 2007), conservation agriculture (Knowler \& Bradshaw 2007) and to some extent Landscape Character Assessment (LCA) techniques which seek to identify landscape units based on cultural and environmental features (Swannick 2002). Indeed, the 
FLA can be seen as one of many integrated landscape approaches which have emerged in recent years as a means of conceptualising and reconciling the tensions between conservation and development at multiple scales and with multiple stakeholders (de Groot et al. 2010; Sayer et al. 2013; Milder et al. 2014). This is exemplified in the case of dambos, where degradation in the form of soil erosion and gullying has been attributed to destructive upland catchment land use activities such as deforestation and intensive agricultural production (McFarlane \& Whitlow 1990). The FLA recognises such linkages and proposes a range of physical measures to mitigate and adapt to the negative impacts; measures which include afforestation initiatives, the designation of natural vegetation buffer zones around dambos, contour terracing, and composting; all of which are key components of an integrated, holistic system of wetland management. Critically, however, the FLA acknowledges the importance of engaging local people and community-based social structures in facilitating these measures, and drawing upon the conceptual roots outlined above, seeks to build capacity for local institutional arrangements to co-ordinate and regulate land use activities across the catchment and dambo, both as a means of controlling potentially damaging practices but also in promoting environmentally, socially and economically sustainable practices.

As an entry point to local institutional capacity building, SAB first undertook participatory assessments of community needs and existing livelihood assets in each of the three villages in order to build up a picture of existing institutional structures and arrangements. While these drew attention to existing communitydeveloped bylaws relating to the conservation of forest and water within the area, there was no evidence of institutional arrangements or bylaws dedicated to ensuring sustainable dambo management. This perceived institutional gap, therefore, was addressed through the participatory development of new institutional arrangements for dambo use.

\section{b) Building local institutional capacity}

The institutional linkages (Figure 2) established within the SAB project centre on MALEZA's previous project experiences of establishing various village development clubs ('MALEZA Clubs'), membership of which was open to anyone within each specific village with an interest in development and the improvement of rural livelihoods (usually around $80 \%$ of households became members). Within each target community these clubs were established to complement and inform the government-driven Village Development Committees (VDC), democratically elected institutions overseen by the village headman which are involved in planning, supervising and implementing development activities at the grassroots level (DLG, 2001). Subsequently, as the SAB project progressed, community members were encouraged to form new clubs, including a 'Village Natural Resource Management Committees' (VNRMC). Although initiated by MALEZA and $S A B$, these particular institutional structures have their origins in The Forest Act (1997) and the Community Based Forest Management Act (2003) which endorse the idea of community based institutions for forest management along with the development of appropriate bylaws relating to sustainable utilisation of forested areas. Through direct engagement with local farmers, MALEZA has, in effect, driven forward this idea and pioneered its integration within the FLA as an approach to also include managing dambos and their catchments.

Like the VDC, VNRMCs are headed by the village headman and are composed of elected community members. Within the VNRMCs, MALEZA has encouraged the development of dambo utilisation bylaws; this is undertaken independently by the committee, although MALEZA have backstopped this process to ensure bylaws are compatible with those that exist in other areas of community governance. The bylaws were also developed with the co-operation of the village headman and approved by the local traditional authority. These bylaws (Table 1) were subsequently approved by the District Development Office, and the District Forestry Office.

In each village the VNRMC meets at least once a month, discusses any resource management issues arising and examines any breach of the rules by the members of VNRMCs and the community at large. Failure of the committee members (or all members) to attend a meeting can result in a fine being imposed (in Katema this included the village headman on one occasion). Similarly, failure to adhere to the bylaws can result in fines, but to date this has not occurred. 
Bylaws differ slightly between sites, but generally include:

- Designating a five metre buffer zone from the centre of the wetland (stream channel), in which no cultivation is allowed.

- Ensuring livestock are always supervised in the wetland.

- Designating specific areas within the wetland for livestock grazing.

- Prohibiting the removal of indigenous trees from the wetland.

- Plant crops in basins to use water efficiently (Malawila).

- Allowing only people from the village of Chiotha and affiliated villages access to Mandela wetland.

- Planting of Eucalyptus trees in the wetland is prohibited.

- Limiting the area of sugar cane when water is short for much of the year.

Table 1 - VNRMC bylaws for community-based dambo management.

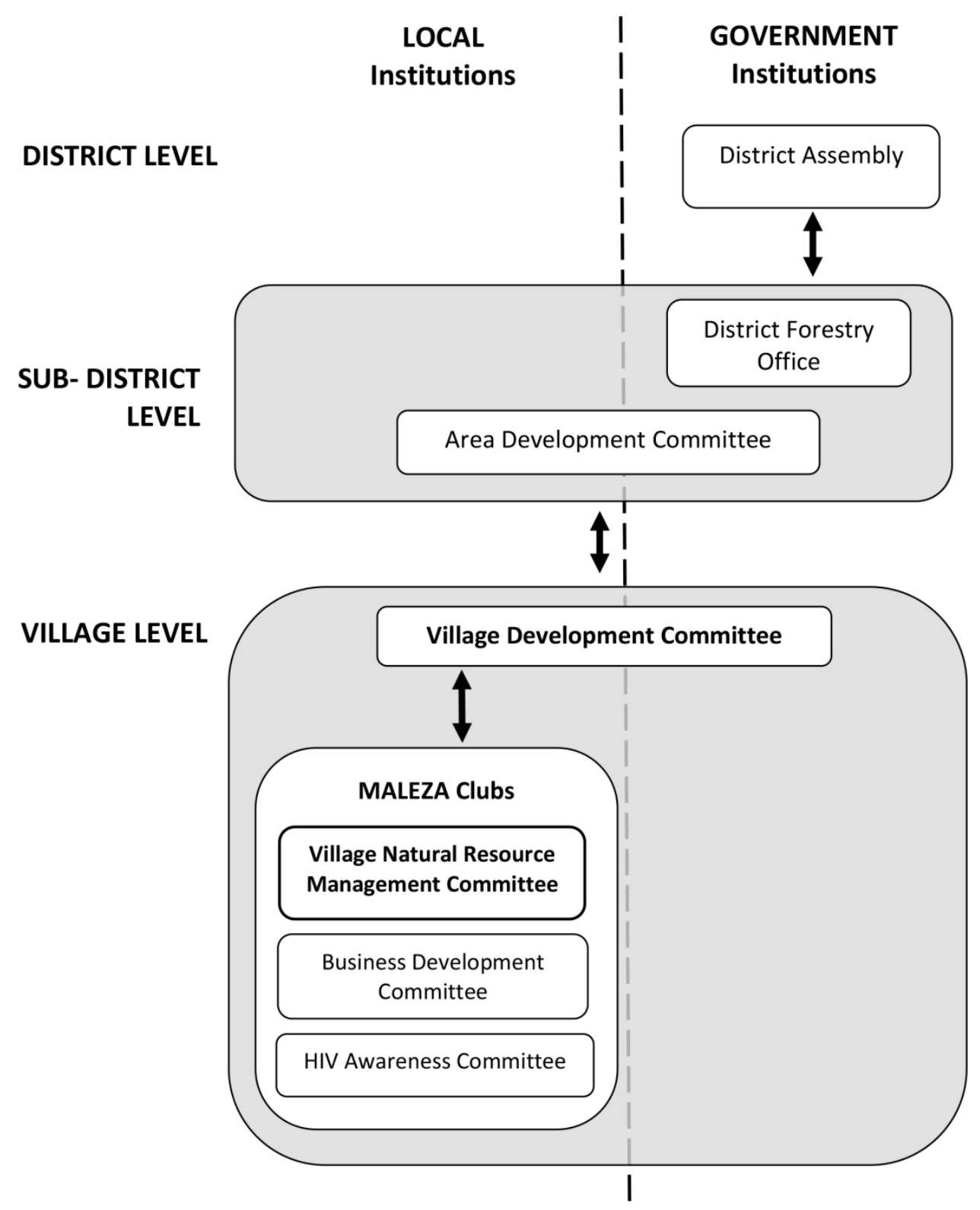

Figure 2 - Institutional linkages within the SAB project. 
The evolution from these village clubs into the more formal VNRMCs headed by the village headman, was seen as a critical stage towards establishing a body of support within the community if difficult decisions have to be made about land use and land allocation arrangements. For example, there may be pressures on village headmen to allocate all the dambo to people for cultivation, which then makes it impossible to retain areas of natural vegetation which sustain critical regulating and supporting ecosystem services. Addressing issues such as these, which in time could affect many people, requires strong community support and adaptation by all dambo users.

\section{Researching $S A B^{\prime} s$ local institutional impact}

A criticism often levelled at NGO-driven community-based development projects is the lack of accountability, evaluation and follow-up once the project or funding has ended (Wenar 2006; Gent et al. 2013). Few resources, if any, are earmarked for impact studies several years after a project, yet few would argue against the need for this as an integral component of projects which aim to deliver sustainable developments. This, therefore, was the rationale for our investigations; the need to ascertain whether, five years on from the cessation of the $S A B$ project, its local institutional capacity building activities have broadly been successful and sustainable.

The research team, consisting of an ex-patriot researcher, one field translator, and one MALEZA extension agent, visited the SAB sites in Simlemba TA over a period of six days during May 2012, some five years after the cessation of the project. As highlighted above, the intention here was to talk to various community members from the three sites with a view to identifying first, the legacy of the SAB approach in general terms, and then more specifically the effectiveness and sustainability of the local institutional arrangements. Drawing upon the work of Chambers (1997) the research adopted a qualitative, participatory approach to data collection, which was sensitive to the need for inclusiveness and representation during discussions, but also respectful of the time demands of community members. Specific methods included a two hour community-led transect walk at each site, and an open group discussion based on a participatory timeline exercise which lasted approximately two hours. Community participation in the research varied from site to site: at Malawila 6 women and 8 men attended the group discussion, at Katema 4 men and 4 women, and at Chiotha 20 men and 8 women attended. Data was recorded in the form of real-time translations of participant responses, and later analysed inductively for the key themes and issues emerging.

There were clear limitations with the work and methodology adopted. Researchers were mindful of the fairly rapid nature of the investigation and the issues this raises in terms of generalisation, coverage and community participation (see Campbell (2002) for a discussion of the limitations of Rapid Rural Appraisal methodologies). Moreover, the issue of positionality in the research was significant; the presence of the original $S A B$ project co-ordinator may have biased the responses so that the positive outcomes of project interventions were overstated in the desire to please, and to increase the likelihood of future NGO intervention in the community.

\section{Results}

\section{a) The broad legacy of the SAB project}

From initial discussions with participants it was clear that both SAB and MALEZA have had a significant impact in each of the three communities. Table 2 shows the range of interventions, knowledge and benefits that participants identified as originating during the project phase, many of which continued to be adopted at the time of this research. Overall, despite some problems being identified such as insect pests and fraudulent activity within the business committee at Malawila, the livelihood benefits of the SAB intervention were regarded as positive and sustained.

\section{b) The use and benefits of dambos}

At Katema, participants discussed their on-going use of the dambo in the context of the 'irrigation' support that they gained from $S A B$, stating that prior to the project they had little knowledge of dambo cultivation. In their own words, this element of SAB's activities has been particularly successful, leading to: 


\section{Malawila}

'Dambo cultivation'

'Contour ridges'

'Composting'

'Livestock'

'Agricultural inputs'

'Afforestation'

'Planting techniques'

'Shallow wells'

'Cultivation beds'

'Soil fertility and

improvement'

'Business development'

'Water management'

'Natural resource committee'

'HIV/AIDS Committee'

\section{Chiotha}

'Contour ridges'

'Tree planting and

afforestation'

'Vegetable production'; 'Crop

diversification'

'Legumes'

'Composting and manuring'

'Business development'

'VNRMC'

'Dambo water management'

'Dambo production'

\section{Katema}

'Composting'

'Forest management'

'Contour marker ridges'

'Irrigation'

'HIV/AIDS knowledge'

'Livestock development'

'Business development'

'Fruit production'

'Dambo management'

'Energy saving stoves'

'Intercropping'
Training

Training and equipment (spirit levels)

Training and constructed compost

beds

Chickens and goats; livestock

husbandry training

Seeds; wheel barrows, treadle

pumps

Training; seedlings provided

Training on seed spacing

Construction of wells in dambo

Construction and demarcation of

beds

Agroforestry - Tephrosia

Training; committee established

Training

VNRMC established

Committee established (family

planning)

Training and equipment

Training; seedlings provided;

Training; seeds

Soya bean seeds

Training and constructed compost

beds

Training and support

Committee / club established

Training; rules in VNRMC

Training; Seeds

Training and constructed compost

beds

Training and VNRMC

Training and equipment (spirit

levels)

Training; treadle pumps

Training; committee established

Training; goats supplied

Training (savings and loans)

Training; seedlings

Training; bylaws established

Training

Training
'We cultivate tomatoes and legumes'

'Increased crop yields', 'Helps control runoff'

'Increased yield'; 'Labour intensive'

'...most have died'

'Increased production'; '...but need replacing'

'...creates buffer zone to dambo'

None cited

'...water for domestic use'

None cited

'Improved soil fertility'; 'Craft material'

'Beer brewing'; 'Biscuit making'

'Water conservation'; 'Control erosion'

'Teaching people about dambos'

None cited
2006

2006 -

2007

2005 -

$2002-2006$

2005

2006 -

2006 -

2006 .

$2005-$

$2005-2007$

2006 -

2006

2006 -

2005

crops'

'Construction material'; 'Cash'; NTFPs 2005 -

'...variable yields'; 'Pest problems'

2005

'...sold for cash'

$2005-$

'Soil and water conservation'

$2005-$

'We are selling seeds'; '...clothes trading'

'Bylaws'; 'Resource management'

'More water available'; 'Increased yields'

'...more vegetables being produced'

$2005-2009$

2005 -

2005

2005

'Improved the soil fertility'

2005

'...relish, mushrooms...fruit...beekeeping'

2005

'Conserve moisture'

2005

'Knowledge'; 'Food security' 2005

'...we learned about prevention measures' 2005 -

'Successful breeding...everyone has 2005 -

benefitted'

'Beer brewing'; 'Fritters'; 'Honey' 2005 - 2009

'...have mangoes, bananas and guava' 2005

'...we are getting higher yields 2005

None cited 2005

'...millet, cassava and beans are produced' 2005

Table 2-SAB Project interventions and their impacts as identified by participants. 
'...higher crop yields... there is food security... we have relish and we can even sell some of our crops... With the money from selling crops we have been able to buy cell phones, radios, kitchen utensils, buckets, and pay for school fees.'

Katema Farmer, $8^{\text {th }}$ May 2012

The advantage of dambo use is that it is able to supply food all year round, and there was agreement among farmers at all sites that crop yields within dambos are always higher than those on the uplands. In particular, dambo use has facilitated an increase in the production of vegetables, particularly at Chiotha, where farmers cited the main limiting factor of production as fluctuations in market prices rather than environmental factors.

At Malawila, although farmers had engaged in dambo use prior to the SAB intervention, they conceded that $S A B$ had changed the nature of their interaction:

'We were given some knowledge about how to conserve water in dambos and get higher yields. We were told about water and erosion control. We didn't have any knowledge of these issues before 2006.'

Malawila Farmer, $5^{\text {th }}$ May 2012

When questioned about the impacts of dambo use on food security, however, farmers suggested that the benefits were not universal across the community:

'Some people get high yields...those who are willing to work hard and those who use fertiliser... Some people are lazy and not willing to farm, but if they are willing they can have access to the dambo'

Malawila Farmer, $5^{\text {th }}$ May 2012

Indeed, a key theme emerging from discussion at all three sites is the issue of differential use and access to dambo land. Not everyone within the MALEZA club membership or the wider community is using dambo land, but rather than this being due to restricted access, it was suggested that use is determined more by a gendered 'willingness to work':

'Most of the people using dambos are women. They are the ones willing to work... it complements their domestic duties. Most of the men are not willing to work in the dambo. Men prefer beer [laughter].'

'Men don't like to work in the dambo because it's groupwork, and most of the men prefer to work individually'

Katema Farmer, $8^{\text {th }}$ May 2012

This raises a further important point in terms of understanding how the socio-economic and socio-cultural context shapes dambo use and the ways in which local institutions seek to manage them. Dambos, as seasonal wetlands, are challenging marginal environments to farm and as such necessitate collaboration and co-ordination if cultivation is to be viable.

\section{c) The role and significance of local institutions}

It is perhaps significant that while each of the participatory group sessions began with a request for participants to identify and discuss all the interventions that SAB had initiated during its project phase, at none of the three sites did participants identify the development of local institutional arrangements. Only with some prompting from the research team after initial discussions did participants acknowledge that SAB and MALEZA had initiated the village development clubs as well as VNRMCs and their associated bylaws. It was felt at the time that this failure to identify them could reflect either the way in which the 
initial question was posed, participants' focus on the more practical, tangible benefits of SAB (outlined above), or ultimately the perceived irrelevance (and potentially declining importance) of the local institutional arrangements. With further prompting, however, participants were able to elaborate on a range of issues relating to local institutional arrangements.

At Katema, participants outlined how MALEZA had assisted them in the setting up of a VNRMC in 2005, initially with 10 members, whose function continues to be the enforcement of the bylaws developed during the SAB project phase (see Table 1). Those bylaws specifically mentioned by participants included the requirement for all members to attend VNRMC meetings, the protection of forest around the village, maintaining buffer zones of non-cultivation around dambos, restricting cultivation in the centre of dambos ('We don't cultivate alongside the stream in the dambo'), and rules for crop spacing within dambos. Penalties for breaking the bylaws are similarly administered by the VNRMC, endorsed by the district administration, and include fines of up to 2500 Kwacha for burning trees in the uplands. What is unclear at Katema, however, is the extent to which the VNRMC retains influence and authority within the wider community, since according to participants, it exists almost as an executive arm of the MALEZA village club. Furthermore, while membership of the MALEZA club was reportedly almost universal during the early stages of $\mathrm{SAB}$, membership has gradually declined to 19 members.

'Some members don't follow the rules and that is a problem... they are not interested in following the bylaws'

Katema Farmer, $8^{\text {th }}$ May 2012

In exploring the reasons for this, participants suggested that perhaps, paradoxically, it has been the development of bylaws and rules for engagement with natural resources that have in fact disincentivised some people from taking part. In effect, the advantages of club membership, in terms of access to the benefits of reserved areas of upland and dambo, seed distribution, extension training and reciprocal help, are not perceived to outweigh the disadvantages of having to participate in laborious collective action and adhering to bylaws which impose restrictions on individual freedom. This decision is undoubtedly influenced by other factors, not least the existing availability of livelihood assets to the individual; wealthier farmers arguably have less to gain from their involvement than the poorer or landless.

The situation at Chiotha largely echoes the experiences of Katema. The MALEZA village club is similarly composed of community members who:

'...come from this village and include those who are interested in what the club stands for, and who are willing to participate in activities'

Chiotha Farmer $3^{\text {rd }}$ May 2012

Again, the VNRMC exists as a sub-committee of the MALEZA club, and hence is made up of a relatively small section of the community (although unlike Katema, the MALEZA club in Chiotha has a reported membership of around 40 village members). In addition to overseeing and encouraging care of the forest (through bylaws), the VNRMC has a specific responsibility for dambos:

'We encourage planting because it means more water will flow into the dambos. We tell people to cut down trees. We teach people to cultivate in the centre of the wetlands to avoid soil erosion... Everyone listens to our advice.'

Chiotha Farmer, $3^{\text {rd }}$ May 2012

These measures were widely regarded by participants as being successful, with the gradual return of natural vegetation in the catchment, an abundance of water in the dambo, and an increasing supply of vegetables being cited as evidence for this. Unlike Katema, there was little evidence at Chiotha of declining membership of the MALEZA club or the VNRMC. Meetings between the VNRMC and the village headman take place once per month and this, according to participants, allows any issues of degradation, 
deforestation or 'rule breaking' to be addressed, or recommendations made. Meetings are well attended and it was suggested that they play an important role in 'extending knowledge to others'.

In Malawila village the experience of the MALEZA club and the VNRMC is more variable. Here, similarly, farmers discussed SAB's positive impact on dambo use and people's livelihoods in terms of the provision of seeds, equipment and training, which has resulted in an increase in water availability and crop production:

'There is more moisture in the dambo and the stream doesn't dry up. When the stream has enough water in it then we have enough yield, but when it is dry we don't. Even when the rains are low the dambo doesn't dry up completely because of the conservation of sedges here.'

Malawila Farmer, $7^{\text {th }}$ May 2012

Moreover, the structure of the VNRMC, its relationship with the MALEZA club, and the bylaws at Malawila are broadly consistent with those of the other SAB sites; fines of up to 50 Kwacha are imposed for noncompliance, and it was suggested that these are strongly supported by the village headman:

'We make sure that everyone can have access to water from the dambo. Sometimes the water is diverted in canals, so we have to make sure that those people downstream also get enough water... If people take too much water we will take the case to the village headman.'

Malawila Farmer, $5^{\text {th }}$ May 2012

Despite having developed a host of bylaws, and indeed, a separate sub-committee for 'dambo irrigation', participants at Malawila expressed some concern, however, that since the end of SAB the general level of interest in participating in local institutional arrangements has declined:

'Now people are not co-operating as much with each other... they are not seeing instant benefits.' Malawila Farmer, $5^{\text {th }}$ May 2012

'Since the introduction of the government subsidy for seed and fertiliser, fewer people are interested in participating in MALEZA club activities. People think there is no point contributing if you already have the benefits of seed and fertiliser'.

Malawila Farmer, $5^{\text {th }}$ May 2012

Although the extent of the 'drop-out' rate of farmers was unclear, the experiences at Malawila would appear to echo those at Katema in terms of a gradual decline in co-operation among MALEZA club members which, in a vicious circle, may undermine the authority of the VNRMC. Even though, as participants suggest, the benefits of $S A B$ have been clear for all, the impression given is that five years on from the direct intervention activities of the project, the economic benefits linked to its local institutional legacy are becoming less tangible for some, and hence participation in local institutional arrangements and the resource use activities associated with them, have become less attractive or worthwhile. Nonetheless, there is little doubt that these arrangements continue to serve an important function for those who retain interest in the MALEZA clubs, and rather than fatalistically accepting that their influence will decline over time, there was a recognition at all three sites that these institutions should adapt and be strengthened:

'We need to elect new members with more responsibility... we need to re-organise'

Malawila Farmer, $5^{\text {th }}$ May 2012

'The bylaws are sufficient at the moment, but if we need some more we will get together with the community agricultural workers and discuss what is needed.'

Chiotha Farmer, $3^{\text {rd }}$ May 2012

'We need to get support from the village headmen to make the bylaws stronger.'

Katema Farmer, $8^{\text {th }}$ May 2012 
Overall, while it is difficult to draw any firm conclusions from the various discussions held given the 'snapshot' nature of the evaluation, what does emerge is a sense that although SAB has produced tangible benefits for the local environment and peoples' livelihoods (at least in the eyes of the farmers), the effectiveness of the local institutions established to facilitate these benefits is being compromised, which has implications for sustainability. The key issue here seems to be the decline in membership and engagement in some resource management activities, including dambo use, which as acknowledged by farmers themselves, reflects the perceived lack of benefit in participating. This echoes Pretty \& Ward's (2001, p212) observation that, 'For farmers to invest in these approaches, they must be convinced that the benefits derived from group or joint or collective approaches will be greater than those from individual ones'. Clearly this is not perceived to be the case in some of the SAB sites, which raises fundamental questions about the nature and functioning of these institutions and the 'collaborative approaches' they have attempted to encourage.

\section{d) Emerging lessons from the SAB Institutions}

Even considering the positionality of the field research team and the likelihood of 'skewed' responses, the picture emerging from the SAB field sites five years on is that the project did have a significant impact on the ways in which communities use and manage the wetland-catchment system. The project has been successful in building human capital in terms of knowledge and skills among some members of the community, and this has led to the continued implementation of specific dambo and catchment management practices which have benefitted livelihoods. While the evidence for environmental improvement is somewhat anecdotal, there is certainly no qualitative indication of environmental degradation occurring either in the catchment or dambo as a result of the FLA interventions, and this, it could be argued, reflects the modest success of the institutional arrangements put in place to regulate their management. As highlighted above, however, there has undoubtedly been a decline in committee membership and influence, and a general feeling among those who took part in the sessions that more work needs to be done to strengthen institutional arrangements. This raises concerns over their sustainability in the long-term, and hence subsequently the sustainability and resilience of the dambo socio-ecological system.

In seeking an explanation as to why this situation may have arisen, here we briefly turn to consider the characteristics of SAB's institutional capacity building intervention in the context of Ostrom's design principles for long enduring CPRs. Although there is consensus that these should not be regarded as a definitive blueprint of the characteristics of sustainable and unsustainable local institutions, they continue to be a useful tool for identifying 'institutional robustness' (Quinn et al. 2007, p102) and highlighting the complexity of these systems.

1. Do the resources for which the institutions exist have clear defined boundaries, and is there a clear demarcation of the resources users?

This first principle suggests that clear resource boundaries and clearly defined resource users are an important pre-requisite to successful institutions. Within Simlemba both the MALEZA clubs and the VNRMC in each of the sites are village-based and hence have jurisdiction over a specific community of individuals and resources (dambo and catchment) that fall within their geographic boundary. In each of the three sites, however, dambos and catchments extend upstream and downstream, and hence some resource use that affects $S A B$ site users is beyond the control of the specific village-based local institutions. Of more potential significance perhaps, is the issue that not everyone within the village community uses the resources that the VNRMCs aim to regulate; and even this is variable over time.

\section{Is there congruence between appropriation and provision rules and local conditions?}

This principle relates to the extent to which the institutional rules of engagement are nested within, or adapted to, the characteristics of the socio-ecological system. In the case of $S A B$, there is evidence that rules have been developed which are both feasible and practicable, and reflect the resource base itself, e.g. as in the case of dambo water allocation cited in the previous section. As Cox et al. (2010) point out, this principle also infers the issue of whether the costs incurred by compliance with the rules of the institution 
are outweighed by the benefits; successful institutional arrangements ensure there are equitable benefits as a result of involvement. Clearly the picture emerging from the SAB sites is one where this is the case for some people but not all. For some community members it is simply more hassle than it is worth to actively engage in committee business (or at least the benefits of compliance and participation are not immediately clear).

\section{Can individuals affected by the rules participate in modifying them?}

There remains a lack of clarity and consistency between the SAB sites with regards who can influence and contribute to decision-making within the VNRMCs. As highlighted above, each VNRMC has a committee membership who oversees the compliance with bylaws, but while the VNRMC seeks to influence behaviour even among non-committee members (i.e. the wider community) there is no evidence that the latter are able to contribute directly to the development or modification of VNRMC rules. Herein lies a fundamental problem; as it stands the VNRMC seeks to universally influence people's relationships with wetlands and catchments, yet because it has been developed as an extension from pre-existing externally-driven structures, the MALEZA clubs, it is exclusive in its membership. Only if you become a 'member' of the VNRMC do you have the opportunity to influence its policy and decision-making.

4. Are there mechanisms in place to monitor both compliance with the institutional rules, and the socioecological impacts of the rules?

The VNRMCs rely on passive, informal monitoring of bylaw adherence and socio-ecological change. For example, if members notice trees being cut down in the catchment, or excess water being removed from the dambo, they will report the matter to committee members or the village headman. Irrespective of whether you are a 'member' of the VNRMC or not, the VNRMC seeks to apply its bylaws throughout the community.

\section{Are there graduated sanctions for those who break the rules?}

Similarly, the institutions at all three sites have the power to impose fines, albeit through the village headman, for non-compliance or rule-breaking. Typically this involves the guilty party paying between 50 and 2500 Kwacha, depending on the severity of the issue. Fines are imposed for activities such as cutting down trees, starting fires or water over-abstraction.

\section{Are there mechanisms in place to resolve conflicts among resource appropriators?}

As per above, any conflict arising through resource over-exploitation is referred in the first instance to the village headman. Farmers at Katema pointed out that the bylaws they had established were further endorsed by the district administration, and hence if the conflict could not be resolved at the local level, it was referred to the Area Development Committee. There is evidence that these mechanisms, as well as the monitoring systems and graduated sanctions, have been successful; only a handful of cases of noncompliance were cited as emerging each year.

\section{Are the rights of appropriators challenged by external government authorities?}

In its widest sense, this principle refers to the critical role played by external actors in the support of local institutional arrangements, and as suggested in the first section of this paper, whether they facilitate an enabling or disabling environment for local institutional interventions that facilitate sustainability. Government is clearly supportive, as evidenced by the endorsement of bylaws, and this has arisen arguably because the VNRMCs were themselves an external government-driven initiative. MALEZA similarly, has played a fundamental role in actually implementing the development of these institutions and their arrangements for wetland and catchment management. It could be argued, however, that many of the institutional sustainability issues highlighted in this discussion have their origins in the way in which the institutions were developed during the $S A B$ project. Irrespective of the extent of participatory development, the current institutional structures are the outcome of an externally driven initiative, and one which sought to embed institutional arrangements within existing externally-driven structures (MALEZA clubs) which were never wholly inclusive. 


\section{Are governance activities organised in multiple layers of nested enterprises?}

Ostrom's final principle infers the importance of congruence between institutional arrangements at different scales. In Simlemba, VNRMCs have jurisdiction over dambos and catchment resources at the village level, but these are also part of a larger catchment or stream network where, ideally, similar institutional arrangements for managing the resources therein, would be evident. The short-term nature of the project, however, meant that the institutional structures and arrangements at the three SAB sites are unique and are not nested. This raises further the issue highlighted in principle 1 with regards their longterm effectiveness in the face of upstream or downstream resource use which is compatible with the local institutional goals.

Looking at the SAB institution experience through the lens of Ostrom's principles reveals that while the local institutions do appear to meet all of the criteria, they do so to varying degrees. This undoubtedly reflects the sheer complexity of each local socio-ecological context, and the limitations of Ostrom's prescriptive framework that has been widely critiqued for not taking this into account, but it does also draw attention to several issues that have limited institutional effectiveness and which seem to be rooted in their origins as an externally-driven initiative. The most significant of these issues is the way in which local institutional arrangements were facilitated through the existing MALEZA club structures. While these clubs were originally established for 'those interested' in participating, for various reasons (e.g. the lack of livelihood assets and capability, or desire) not everyone within the community actively participated in them. It is perhaps unsurprising, therefore, that the VNRMCs that emerged from the MALEZA club model have struggled with issues of inclusion and ownership within the wider community; a situation which is ultimately not conducive to effective collaborative arrangements for resource management. From Ostrom's perspective, however, 'those interested' are arguably analogous to the 'clearly defined' resource users, hence the issue of wider coverage and inclusion should not matter. Yet it does matter in the Simlemba sites for the very reason that the resource users are seeking to recruit more people into their institutional arrangements and impose the related bylaws on the community as a whole, and as outlined in principle 3 above, not everyone affected by the rules has the power to influence them.

The second key issue that emerges relates to principle 2 and concerns the reported decline in membership of both the MALEZA clubs and the VNRMC. Fewer members mean fewer people engaging in SAB / FLA activities, which subsequently erodes the institutional capacity and credibility of those who remain. Those who have left the committee have evidently done so simply because there were more cost-effective tangible benefits to be had through other activities. Staying within the institution, following the rules, and engaging in the labour intensive collaborative working arrangements that dambo cultivation or catchment afforestation require, was no longer advantageous. But to what extent does this reflect the failure and demise of these institutional arrangements? Clearly, the resource use benefits have to outweigh the costs attached to participation in institutional arrangements. Whether this works for individuals ultimately depends on a combination of their own socio-economic circumstances, the 'rules of engagement' as established by the local institution, and the nature of the resource itself. It could be argued that declining membership (and indeed the level of involvement more generally) simply reflects the reality of socioecological variability within these areas; here there is socio-economic differentiation among farmers, and an externally-driven resource management institution that supports farmer engagement in activities with attractive short-term returns to labour (dambo cultivation) on the proviso that they also engage in labour intensive activities that result in less tangible benefits (catchment soil and water conservation). Evidently this is attractive for some, but not others, and it is likely that engagement in these activities, and indeed dambo use itself, is regarded as a stepping stone to better things for many farmers, hence the observed drop-out. The case of the Business Development Club at Katema perhaps illustrates this:

'... we are no longer working as a group. It's all individual businesses now. We have our own capital so we don't need to work as a group.'

Katema Farmer, $3^{\text {rd }}$ May 2012 
It is difficult to comment on whether this issue could have been avoided by SAB and MALEZA, not least because the question of how to retain community interest in institutional arrangements that seek to balance environment-development outcomes, goes to the core of environment-development debates. What is clear, however, is that the SAB institutions being nested within the externally-driven MALEZA clubs has not helped the situation, since as discussed earlier, this has resulted in a lack of congruence between resource user groups and the resources within the village catchment.

It is worth noting here that while much of the discussion has been underpinned by an assumption that strong and inclusive institutional arrangements can be facilitators of a sustainable dambo socio-ecological system, the situation within the SAB sites is one where a decline in collaboration and co-ordination has actually led to reduced pressure on dambos themselves, simply because the management of dambo areas was deemed too challenging for individuals working alone. This has positive implications for environmental sustainability in terms of maintaining 'natural' ecosystem services, but there is inevitably a trade-off here with food production and hence the wider socio-economic wellbeing of the community. This is one of the tensions that local institutional arrangements must be able to address.

\section{Conclusions}

In reviewing the case of the Striking a Balance project and its involvement in building local institutional arrangements in Simlemba, this paper has sought to interpret project experiences in the context of the literature on CPR institutions in an attempt to draw some lessons for the future. This has been centred on the question of whether local institutional arrangements that seek to balance environment and development outcomes, can be facilitated successfully by external agents. What the discussions with members of the Simlemba community indicate, is that there have been some notable successes emerging from the SAB project in terms of the actual implementation of soil and water conservation measures, sensitive dambo use, and the development of bylaws and local institutions to take these forward and promote awareness of catchment-wetland linkages. Five years after the formal cessation of $S A B$, farmers from each of the three project areas report that while many $S A B$ activities continue to be implemented, the institutional arrangements have failed to prevent a small but noticeable decline in farmer engagement in these activities, which has implications for the long-term sustainability of the socio-ecological systems in these areas. In seeking potential explanations for this decline in institutional functionality, the analysis within this paper has highlighted several inconsistencies between Ostrom's design principles for successful CPR institutions, and the SAB institutions. Although there is clearly a need to exercise caution in being too prescriptive about the preconditions for successful institutions given the recognised complexity of socioecological contexts, what emerges from the analysis here is a sense that despite great effort being taken to be participatory and inclusive during the institutional capacity building phase of the project, the effectiveness of the SAB institutions were compromised from the start by being nested within pre-existing, externally-driven village clubs. While this seems to have been done as a means of speeding up the process of bylaw development and providing an institutional basis for physical implementation activities in the catchment and wetland, the consequence is that these arrangements were never devolved completely within the community, resulting in a lack of common ownership and a ultimately perception by some that this was another club that could be opted in and out of. Yet, the challenge of implementing sustainable environment-development outcomes is clearly beyond the scope of a village club.

This review of the SAB case has illustrated that while local institutional development can be externallydriven and facilitated, and result in significant benefits for resource users in the short to medium-term, the long-term sustainability of these institutions and the activities they support arguably requires a much deeper level of institutional capacity building than that undertaken in Simlemba. This ultimately requires a more devolved, longer-term participatory process that draws in all the stakeholders who are likely to be affected by (and hence who should have a voice in) institutional decision-making, and who are impacted upon in one way or another by resource use. The dynamic nature of complex wetland socio-ecological systems renders this process particularly challenging. 


\section{Acknowledgements}

The authors wish to thank the communities of Malawila, Katema and Chiotha, and also Patrick Thawe and Memory Mwale for facilitating the fieldwork in 2012.

\section{References}

Adekola O, Mitchell G, Grainger A. 2015. Inequality and ecosystem services: the value and social distribution of Niger Delta wetland services. Ecosystem Services. 12:42-54.

Adger WN. 2000. Social and ecological resilience: are they related? Prog Hum Geog. 24:347-64.

Agrawal A. 2001. Common property institutions and sustainable governance of resources. World Dev. 29:1649-1672.

Anderies JM, Janssen MA, Ostrom E. 2004. A framework to analyse the robustness of social-ecological systems from an institutional perspective. Ecol Soc. 9:18.

Balek J, Perry JE. 1973. Hydrology of seasonally inundated African headwater swamps. J Hydrol. 19:227249.

Berkes F, Folke C. 1998. Linking social and ecological systems: management practices and social mechanisms for building resilience. Cambridge: Cambridge University Press.

Berkes F. 1999. Sacred ecology: traditional ecological knowledge and resource management. Philadelphia \& London: Taylor \& Francis.

Berkes F, Colding J, Folke C. 2003. Navigating social-ecological systems: building resilience for complexity and change. Cambridge: Cambridge University Press.

Blunt P, Warren DM. 1996. Indigenous organizations and development. London: ITDG Publishing.

Boast R. 1990. Dambos: a review. Prog Phys Geog 14:153-177.

[CA] Comprehensive Assessment. 2007. Water for food, water for life: a comprehensive assessment of water management in agriculture. London \& Colombo: Earthscan \& International Water Management Institute.

Campbell J. 2002. A critical appraisal of participatory methods in development research. Int J Soc Res Meth, 5:19 -29.

Chambers R. 1997. Whose reality counts? Putting the first last. London: Intermediate Technology Publications.

Chisinga B. \& Kayuni H. 2011. Hedging food security through winter cultivation: the agronomy of dimba cultivation in Malawi. Paper presented at 'From Scarcity to Access and Rights: Changing Perspectives on Food Insecurity' workshop, Center for Development and the Environment, University of Oslo (Norway). [Internet]. [cited 2015 Oct 5]. Available from http://www.academia.edu/1752237/Hedging_Food_Security_through_Winter_Cultivation_The_Agr onomy_of_Dimba_Cultivation_in_Malawi

Cox M, Arnold G, Toma's SV. 2010. A review of design principles for community-based natural resource management. Ecol Soc 15: 38. [Internet]. [cited 2015 Oct 2]. Available from http://www.ecologyandsociety.org/vol15/iss4/art38/

de Groot RS, Alkemade R, Braat L, Hein L, Willemen L. 2010. Challenges in integrating the concept of ecosystem services and values in landscape planning, management and decision making. Ecol Comp. 6:453-462.

Dixon AB, Wood AP. 2003. Wetland cultivation and hydrological management in eastern Africa: matching community and hydrological needs through sustainable wetland use. Nat Resour Forum. 27: 117-129.

[DLG] Department of Local Government. 2001. Development planning system handbook for district assemblies. Malawi: Department of Local Government.

Emerton L. 2005. Values and rewards: counting and capturing ecosystem water services for sustainable development (IUCN Water, Nature and Economics Technical Paper No. 1). Gland: IUCN.

Faulkner RD, Lambert RA. 1991. The effect of irrigation on dambo hydrology: a case study. J. Hydrol. 123:147-161.

Finlayson CM, Davidson N, Pritchard D, Milton GR, MacKay, H. 2011. The Ramsar Convention and ecosystem-based approaches to the wise use and sustainable development of wetlands. J Int Wild Law Pol. 14:176-198. 
Fisher RJ, Magginnis S, Jackson WJ. 2005. Poverty and conservation: landscapes, people and power. Gland: IUCN.

Folke C, Carpenter S, Elmqvist T, Gunderson L, Holling CS, Walker B. 2002. Resilience and sustainable development: building adaptive capacity in a world of transformations. Ambio. 31:5.

Gent SE, Crescenzi MJC, Menninga E, Reid LR. 2013. The reputation trap of NGO accountability. Department of Political Science, University of North Carolina, Chapel Hill. [Internet]. [cited 2015 Oct 5]. Available from https://www.unc.edu/ crescenz/gcmr_reputationtrap.pdf

Hinchcliffe F, Thompson J, Pretty J, Guijt I, Shah P. 1999. Fertile ground: the impacts of participatory watershed management. London: ITDG Publishing.

Holden E, Linnerud K. 2007. The sustainable development area: satisfying basic needs and safeguarding ecological sustainability. Sustain Dev. 15:174-187.

Howes M. 1997. NGOs and development of local institutions: a Ugandan case-study. J Mod Afr Stud. 35:1735.

Kambewa D. 2005. Access to and monopoly over wetlands in Malawi. Paper Presented the International Workshop on African Water Laws, Plural legislative Framework for Rural Water Management in Africa 26-28 January 2005, Johannesburg, South Africa.[Internet]. [cited 2015 Oct 5]. Available from http://projects.nri.org/waterlaw/AWLworkshop/KAMBEWA-D.pdf

Koku JE, Gustafsson JE. 2001. Local institutions and natural resource management in the South Tongu district of Ghana: a case study. Sustain Dev. 11:17-35.

Knowler D, Bradshaw B. 2007. Farmers' adoption of conservation agriculture: a review and synthesis of recent research. Food Pol. 32: 25-48.

Kumar R, Horwitz P, Milton GR, Sellamuttu SS, Buckton ST, Davidson NC, Pattnaik AK, Zavagli M. 2011. Assessing wetland ecosystem services and poverty interlinkages: a general framework and case study. Hydrol Sci J. 56:1602-1621.

Lenton R, Muller M. 2009. Integrated water resources management in practice: better water management for development. London: Earthscan.

[MA] Millennium Ecosystem Assessment. 2005. Ecosystems and human well-being: wetlands and water synthesis. Washington DC: World Resources Institute.

McCartney MP, Rebelo LM, Sellamuttu SS, de Silva S. 2010. Wetlands, agriculture and poverty reduction (IWMI Research Report 137). Colombo: IWMI.

McFarlane MJ, Whitlow R. 1990. Key factors affecting the initiation and progress of gullying in dambos in parts of Zimbabwe and Malawi. Land Degr Rehab. 2:215-235.

Mansbridge J. 2014. The role of the state in governing the commons. Env Sci Pol 36:8-10.

Milder JC, Hart AK, Dobie P, Minai J, Zaleski C. 2014. Integrated landscape initiatives for African agriculture, development, and conservation: a region-wide assessment. World Dev. 54:68-80.

Mimet A, Houet T, Julliard R, Simon L. 2013. Assessing functional connectivity: a landscape approach for handling multiple ecological requirements. Methods Eco Evol. 4: 453-463.

Mloza-Banda HR. 2005. Integrating new trends in farming systems approaches in Malawi. Afr Crop Sci. 7: 961-966.

Msusa H. 2011. Sustainable utilization of wetlands for food security: a case study of the Simlemba Traditional Authority in the Kasungu District of Malawi. J. Dev Sus Agr. 6:86-100.

Newson M. 1997. Land, water and development: sustainable management of river basin systems. London: Routledge.

Noble R. 1996. Wetland management in Malawi as a focal point for ecologically sound agriculture. ILEA Newsletter. 12: 9.

Olsson P, Folke C. Berkes F. 2004. Adaptive co-management for building social-ecological resilience. Environ Manage. 34:75-90.

Ostrom E. 1990. Governing the commons: the evolution of institutions for collective action. Cambridge: Cambridge University Press.

Ostrom E. 2009. A general framework for analyzing the sustainability of socio-ecological systems. Science. 325:419-422.

Mazzucato V, Niemeijer D. 2002. Population growth and environment in Africa: local informal institutions, the missing link. Econ Geogr.78:171-193. 
Pretty J, Ward H. 2001. Social capital and the environment. World Dev. 29:209-227.

Quinn CH, Huby M, Kiwasila H, Lovett JC. 2007. Design principles and common pool resource management: an institutional approach to evaluating community management in semi-arid Tanzania. J Environ Manage. 84:100-113.

Ramsar. 1987. 3rd Meeting of the Conference of the Contracting Parties, Regina, Canada 27 May - 5 June 1987. Recommendation 3.3: Wise use of wetland. [Internet]. Gland: Ramsar; [cited 2015 Oct 2]. Available from http://www.ramsar.org/sites/default/files/documents/library/key_rec_3.03e.pdf

Ramsar. 2005. 9th Meeting of the Conference of the Parties to the Convention on Wetlands (Ramsar, Iran, 1971) Kampala, Uganda, 8-15 November 2005. Resolution IX.1 Annex A: A conceptual framework for the wise use of wetlands and the maintenance of their ecological character. [Internet]. Gland: Ramsar; [cited 2015 Oct 2]. Available from http://www.ramsar.org/sites/default/files/documents/pdf/guide/guidewise-use-2005-e.pdf

Rasmussen LN, Meinzen-Dick R. 1995. Local organisations for natural resource management: lessons from theoretical and empirical literature (EPTD Discussion Paper No. 11). Washington: International Food Policy Research Institute.

Rebelo LM, McCartney MP, Finlayson CM. 2010. Wetlands of Sub-saharan Africa: distribution and contribution of agriculture to livelihoods. Wetl Ecol Manag. 18:557-572.

Ribot JC, Chhatre A, Lankina TV. 2008. Institutional choice and recognition in the formation and consolidation of local democracy, representation, equity and environment (Working Paper No 35). Washington DC: World Resources Institute.

Richards M. 1997. Common property resource institutions and forest management in Latin America. Dev Change. 28:95-117.

Roberts N. 1988. Dambos in development: management of a fragile ecological resource. J. Biogeogr. 15:141-148.

Roe D, Elliott J. 2004. Poverty reduction and biodiversity conservation: rebuilding the bridges. Oryx. 38:137139.

Sayer J, Sunderland T, Ghazoul J, Pfund JL, Sheil D, Meijaard E, Venter M, Boedhihartono AK, Day M, Garcia C, van Oosten CV, Buckk LE. 2013. Ten principles for a landscape approach to reconciling agriculture, conservation, and other competing land uses. PNAS. 110:8349-8356.

Scherr SJ, McNeely JA. 2007. Farming with nature: the science and practice of ecoagriculture. Washington: Island Press.

Schuyt KD. 2005. Economic consequences of wetland degradation for local populations in Africa. Ecol Econ. 53:177-190.

Shivakumar SJ. 2003. The place of indigenous institutions in constitutional order. Const Pol Econ. 14:3-21.

Swanwick C. 2002. Landscape character assessment: guidance for England and Scotland. Cheltenham and Edinburgh: Countryside Agency and Scottish Natural Heritage.

Thomas MF, Goudie AS. 1985. Dambos: small channelless valleys in the tropics. Z Geomorphol Suppl. 52.

Uphoff N. 1992. Local institutions and participation for sustainable development (Gatekeeper Series No 31). London: IIED.

von der Heyden JC. 2004. The hydrology and hydrogeology of dambos: a review. Prog Phys Geog. 28:544.

Watson E. 2003. Examining the potential of indigenous institutions for development: a perspective from Borana, Ethiopia. Dev Change. 34:287-309.

[WCED] UN World Commission on Environment and Development. 1987. Our common future: report of the World Commission on Environment and Development. Switzerland: WCED.

Wood AP, van Halsema GE. 2008. Scoping agriculture-wetland interactions: Towards a sustainable multiple response strategy. FAO: Rome.

Wood AP, Dixon AB, McCartney M. (2013). Wetland management and sustainable livelihoods in Africa. London: Earthscan.

Wood AP, Thawe P. 2013. Catchments and wetlands: a functional landscape approach to sustainable use of seasonal wetlands in central Malawi. In: Wood AP, Dixon AB, McCartney M. editors. Wetland management and sustainable livelihoods in Africa. London: Earthscan; p. 63-84.

Wenar L. 2006. Accountability in International development aid. Ethics Int Aff. 20:1-23. 